\title{
Analyzing President Donald Trump's Measures in Securing The US-Mexico Border Security from Realist Perspective
}

\author{
Siti Nurhasanah ${ }^{1}$, Muhammad Fuad ${ }^{2}$ \\ \{husna.rifa04@gmail.com ${ }^{1}$, faseha.fuad994@gmail.com $\left.{ }^{2}\right\}$ \\ ${ }^{1,2}$ American Studies, School of Strategic and Global Studies, Universitas Indonesia
}

\begin{abstract}
Since presidential campaign in 2016, as a presidential candidate, Donald Trump has made security aspects as one of crucial ideas in the Republican Party platform. The security approach has delivered him to his presidency. After being inaugurated in January 2017, Trump attempted to realize his promises, including securing the US-Mexico border by establishing 10 feet border wall. The author's primary assumption is that Trump using a realist approach to maintain US security. The author uses descriptive qualitative method in this research paper. The authors use realism theory in International Relations to explore and analyse Trump's measures in securing border security. The authors evaluate how Trump applies realism in formulating policies regarding border security and how does realism ideas influence the US foreign policy under the Trump administration. The result and discussion show that the US under Trump administration has significantly modified US foreign policy. However, the US decreases its role in the international arena because of the internal or domestic problem about security that should be addressed. However, the US opens for both bilateral and multilateral cooperation with terms that match the US national interest.
\end{abstract}

Keywords: US-Mexico Border Wall, President Donald Trump, Realism, Border Security

\section{Introduction}

The United States (the US) has borderland with Mexico along the southern part and it often triggers conflicts, particularly the flow of illegal immigrants from Latin American countries through the US-Mexico border to the US. The boundary of the US and Mexico in the southern US can be seen on Figure 1. It lies from San Diego, Nogales (Arizona), El Paso, and Laredo (Texas) in the US side. While in Mexico lies several areas such as Tijuana, Nogales (Sonora), Ciudad Juarez, and Sungai Rio Grande. The starting point of the border wall is in Tijuana (Mexico region) and San Diego (USA). 


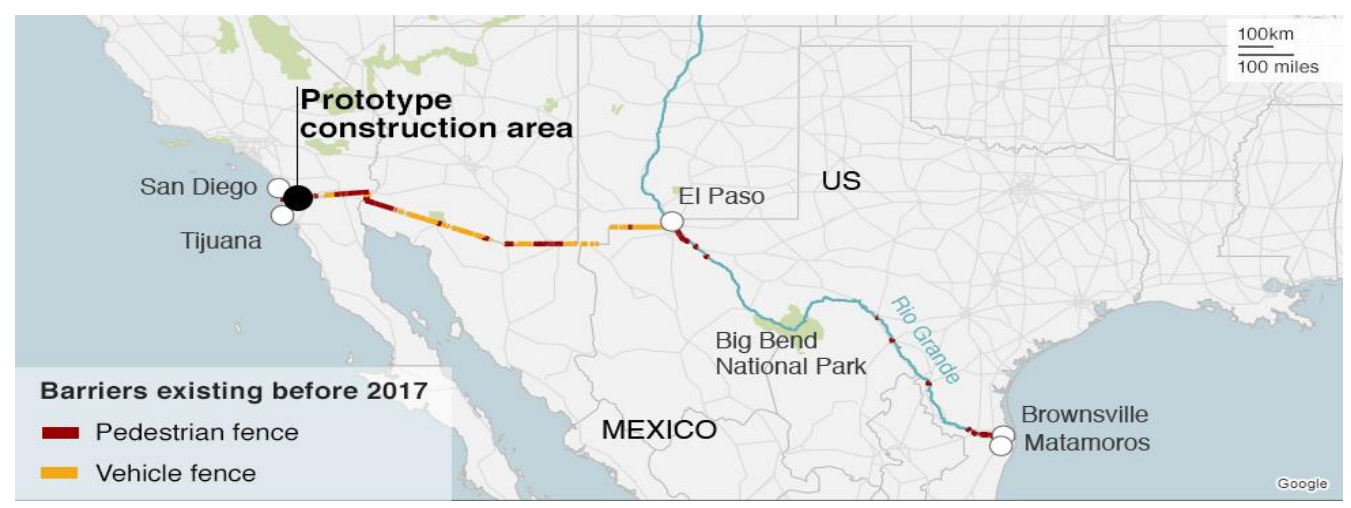

Fig. 1. The Map of the US-Mexico border Source: https://www.bbc.com/news/world-us-canada-46824649

$\mathrm{CNN}$ also states its research result about the timeline of fund estimation proposed by Trump in Figure 2 below:

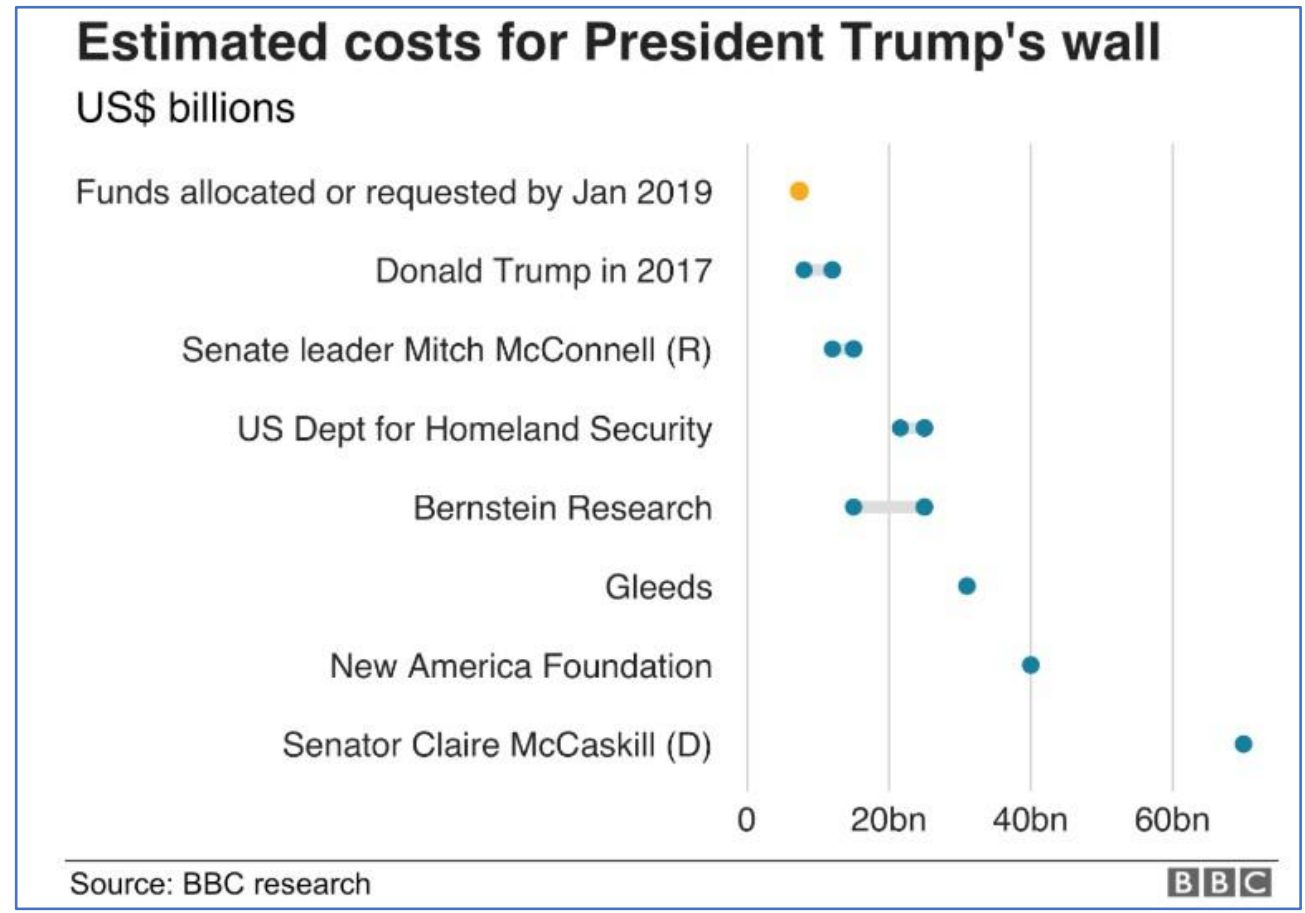

Fig. 2. The Estimated costs for President Trump's wall Source: https://www.bbc.com/news/world-us-canada-46824649 
The controversy of this wall is that some argue that the wall is ineffective physical barriers that reflect the US as a closed society. Nancy Pelosi, Democrat Senator responding to Trump speech from Oval Office about immigration stated that everyone agrees that the US government needs to secure our borders, while honouring American values: US can build the infrastructure and roads at ports of entry; US can install new technology to scan cars and trucks for drugs coming into the nation; US can hire the personnel we need to facilitate trade and immigration at the border; and US can fund more innovation to detect unauthorized crossings (Martinez, Read the Full Transcript of Democrats' Response to President Trump's Oval Office Address, 2019). While Senator Minority Leader Chuck Schumer stated that the US could secure the border without an expensive, ineffective wall through strengthening the immigration border regulation (Martinez, Read the Full Transcript of Democrats' Response to President Trump's Oval Office Address, 2019).

Ville Sinkkonen in his writing entitles "Contextualizing the Trump Doctrine" states that transnationalism realism with civilizational undertones that are attached to the materialist definition of power utilized by the Trump administration, the power of exercise, and transactional mindset that influence Trump in making decision of foreign policy (Sinaga, Ramelan, \& Montratama, 2018, p. 17). While Ewelina Wasko-Owsiejczuk on her piece entitles "The Tenets of Trumpism - from Political Realism to Populism" explores the realism influence on US foreign policy in general. Wasko-Owsiejczuk states that the term 'Trumpism' refers to realism ideas such as putting US national interest first and more assertive attitude of the US towards other countries and organizations (Wasko-Owsiejczuk, 2018, p. 91).

From author's analysis of the literature review, loophole from the discussion is about analysing Trump's policy focuses on the construction of the US-Mexico border wall from a realist perspective. All countries certainly want security for their citizens, and so does Trump, to build a solid fence he needs at least \$ 60bn in total (Rodgers \& Bailey, 2019). Security is not seen as a goal but as a consequence of decent preparation, which can be quickly lost when one lacks an understanding of what it is and how crucial it is. The thesis of this paper is that Trump using his realism, becomes Trump's motivation in formulating US border policies.

\section{Research Question}

How does President Donald's Trump policy of establishing the US-Mexico border wall analyzed from a realist perspective?

\section{Research Method}

The method used is descriptive qualitative by collecting data related to the background Trump's actions to maintain the stability of border security. The author also uses supporting documents from books, scientific articles, various valid sources from the internet, such as news, reports, and other relevant data, particularly those published in the past ten years. To focus, the author confines explicitly the scope of the research from 2016 since the US presidential campaign period until now. 


\section{Theoretical Framework}

According to Dunne and Schmidt, there are three key realist ideas (Dunne \& Schmidt, 2006):

States interact in an anarchic system (non-state actors and domestic affairs are much less significant). The country needs to survive by pursuing power and promoting its national interest (rather than worrying about ideals and ethics). The state needs to practice self-help (maintaining a balance of power by building military capability, forming alliances, and not relying on international organizations).

In International Relations, realism also emphasizes that:

- The world is dangerous and brutal

- States are important actors

- States are Rational Actors

- The primary goal of states is to ensure their security

Dunne and Schmidt also say that realism concept is still debatable until now. Many argue that realism, as the dominant theory in world politics, has been since International Relations began. Realism has a long history and predating International Relations studies. Realism has many variants, which nevertheless all share three key ideas: statism, survival, and self-help. This theory is very relevant to analyze this case because Trump's undertaking in the US-Mexico border is influenced by realism ideas which emphasizes on increasing power to be able to survive. It relates to the concept of America First, which enunciated by Trump even before he is elected to become the president of the US.

\section{Result}

Trump's action in securing the border is under the realism principles. First, a belief that "the world is dangerous and brutal." This principle applied by Trump measures in preventing the aliens (illegal immigrants from Latin America) entering the US. The underlying assumption is that the aliens take American jobs, conduct crimes, and bring drugs to the US. Second, states are important actors. It is no wonder that the US assumes that the domestic security inside the country should be given more attention because the US is the most crucial player in international relations (according to realists) that shape global security. It relates to the core value of realism that tends to see security as achieved by accumulating power in, in other words as "becoming stronger."

Third, states are rational actors. In facing the security dilemma regarding the US-Mexico border, Trump has two possible options: security or humanity. In this case, Trump prefers the security aspect because Trump is representing the US as a rational actor who prioritizes its national interest rather than others. Last, the primary goal of states is to ensure their security. It relates to the previous argument that in realism, countries tend to increase their capabilities both in economic and military aspects to be able to survive and conduct self-help. In realism, the cooperation is not impossible. However, states do not put absolute trust to their partners; the suspicion remains. Therefore, by accumulating power, countries have a safety-net to guarantee their survival.

In the case of Trump, he prioritizes the interest and the safety of the US permanent residents. It aims to guarantee the continuity of the US national interest. He acts as a rational actor, to 
protect the US from the possible threats from other countries, especially illegal immigrants from Mexico and other Latin American countries.

\section{Discussion}

Supporters of political realism, such as Hans Morgenthau, Kenneth Waltz, and John Mearsheimer, understand security in terms of military strength (Wasko-Owsiejczuk, 2018). Because of this kind of condition, countries are in constant competition with one another. Trump sees this as a hint for him to increase US political power. As stated by Justyna Zajac that (Zajac, 2006, p. 16):

"American realists doubt the effectiveness of the international law system and believe that only the US can effectively guard its interests, without cooperation with any other country."

From the statement above, the author implies that Trump representing the US believes that the US is open to have bilateral relationships with other countries with some conditions. As statesman Pericles states, "We alone do good to our neighbors not upon a calculation of interest, but in the confidence of freedom and a frank and fearless spirit" (Gelb, 1975). It implies that even most of Trump's policy is influenced by realism, but it is still possible to have cooperation with calculated interest. Looking at the US and Mexico relationship about the land border, the US is as an injured party by the high number of illegal immigrants entering the US. Nevertheless, the US takes action to make better terms for the US.

According to the Pew Research Centre, there will be a decline in the number of immigrants entering the US. The highlighted decline is from 2007-2014. Despite the fall, the estimated 5.9 million illegal immigrants from Mexico still account for a majority (52\%) of the nation's unauthorized immigrant population (Krogstad \& Passel, 2014). This decrease occurred after the Great Recession. However, the US government, under the Trump administration continues to emphasize the importance of securing the border. The following data shows that more nonMexicans cross the border compared to Mexicans. As illustrated in figure 3 below: 


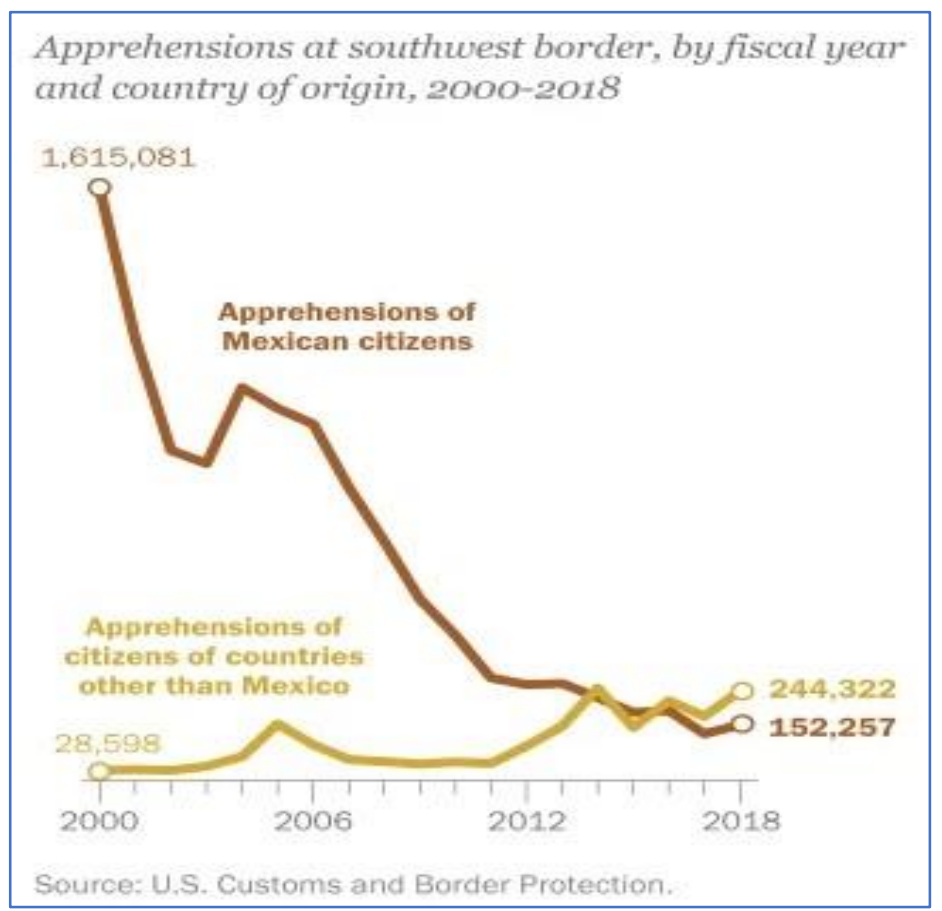

Fig. 3. Non-Mexicans now outnumber Mexicans in southwest border apprehensions Source: https://www.pewresearch.org/fact-tank/2019/04/10/whats-happening-at-the-u-s-mexicoborder-in-6-charts/

From this figure, the author would like to emphasize that Latin Americans make Mexico as an entrance to enter the US; this is undoubtedly a concern of the US government. Not surprisingly, Trump wants to work with the Mexican government to build a wall. Although Mexican President Andres Manuel Lopez Obrador emphatically refuses to fund it (Niquette, 2019).

The America First tagline is Trump's attempt to increase power, because in realism one of its principles is "power is the only reliable way to achieve security." In this regard, Trump, as a US leader, feels to protect US people by strengthening border security. As stated in his speech from Oval House at the beginning of this year (Martinez, 2019):

"Some have suggested a barrier is immoral. Then why do wealthy politicians build walls, fences, and gates around their homes? They do not build walls because they hate the people outside, but because they love the people inside."

By pursuing America First, Trump has shown its intention to protect American from threats which come from outside America. While media critics claimed that Trump wants to convince Americans that an open, pluralistic, and multicultural society is dangerous (Wasko-Owsiejczuk, 2018, hal. 87). Regardless of that criticism, Trump keeps his attempt to maintain security and welfare for the US citizen. 
Realist does not see security as a goal but as a consequence of decent preparation which can immediately vanish when one lacks an understanding of what it is and how crucial it is. Realism tightly relates to Trump approach in international relations. He prefers unilateralism than multilateralism way. That is opposite to Obama approach who prefers the multilateralism one. Unilateralism has had a significant influence on US foreign policy in the $21^{\text {st }}$ century. By the explanation above, the author implies that the US engagement in international politics minimizes the role of government in international organizations. The US also restricts the participation of other government into US domestic matters.

Unilateralists do not accept the necessary compromises to accelerate alliances and oppose the transfer of power to international organizations (Haass, 2004, pp. 116-117). Multilateralism is open to cooperation with other governments and organizations. While unilateralism free to support from allies during military operations, they are sceptical for cooperating with other countries in International Relations, and preferring independent decision making. The US involvement in international affairs should befall on their terms under their interests (Zajac, 2006, p. 17).

In the age of Trump, the lack of engagement in international organizations and cooperation with other countries leads to isolationism. Isolationists claim that the US cannot manage to be active in the international arena due to urgent domestic issues and limited resources (Haass, 2004, p. 79). Trump on his speech from Oval Office when he, for the first time addressing the nation in January 2019, stated that there is a growing humanitarian and security crisis at our southern border (Martinez, 2019). Trump then explained that the humanitarian crisis at the USMexico border is severe and needs immediate action in the form of a wall that prevents the flow of illegal aliens. By that reason, Trump still considers to be active in the international organization because the situation inside the country is more urgent to be solved.

Trump also sees the political matter in this wall issue, because Senator Nancy Pelosi and other Democrats repeatedly agreed the physical barrier in the past when Obama held the administration. But once Trump became the president, they refused that idea (Martinez, 2019). However, in addition, to pursuing the realist measures, Trump has stepped in cooperating with the government of Guatemala, El Salvador, and Honduras as the three biggest countries contributed to the number of illegal immigrants entering the US through Mexico. Trump made significant deals with these three governments (The White House Official Website, 2019).

In the following are the key points of the deals:

The Administration has expanded the Migrant Protection Protocols to require aliens to wait in Mexico while their immigration cases proceed, pursuant to 8 U.S.C. $\S 1225(b)(2)(C)$.

The Administration reached an agreement in principle with Guatemala, consistent with 8 U.S.C. $\S 1158(\mathrm{a})(2)(\mathrm{A})$, to have migrants apply for asylum there.

By the author's analysis, Trump still uses a very rational realist approach and makes mutually beneficial agreements with related parties. While Mexico, for the first time in history, deploying thousands of troops to address the crisis (The White House Official Website, 2019). Another significant progress is that the President is continuing to build the wall, with 163 miles of new border wall system under construction now and 450 miles expected to finish by the end of next year.

Another realistic point learned from Trump administration is that the US government now stops receiving the immigrant illegals to reform the new immigration law focusing on the asylum seekers who are willing to come lawfully to the US. This measure in the realist view is a win-win solution that decreases the deprivation of the US government without overlooking the immigrants who will enrich American society with new colour and culture of multiculturalism. According to the official statement stated in The White House that the US 
expects to receive more than 368,000 new refugees asylum claims in fiscal year (FY) 2020 (The White House Official Website, 2019).

Considering refugees and asylum seekers as part of the same relief effort is an accurate reflection of America's generous protection-based immigration (The White House Official Website, 2019). This intention comes to implementation when, on $26^{\text {th }}$ September 2019, An Executive Order was signed by Trump to ensure the settlement of the refugees to live in an environment with the most exceptional opportunity to thrive, flourish, and contribute to their new American society.

Prioritizing its national interest become the main objective of every administration. By pursuing America First, Trump has successfully implemented a realist attempt always to put the welfare of American citizen first. In other words, the US is accepting refugees with a high standard of screening. By these explanations, the author's assumption is that Trump's action much more makes sense viewed from the realist perspective. As Trump aims at ensuring the welfare and the safety of American citizens based on the US national interest. As a wise proverb in politic stated by Richard N. Haass, "foreign policy begins at home," reflecting the situation of domestic politics will radiate to its foreign policy in the international arena. In this case, Trump would like to make sure the position in the local of the US before going further to be actively involved in regional and international organizations.

\section{Conclusion}

Realism has much influenced Trump's policy regarding the implementation of securing the US-Mexico through the establishment of a border wall. Trump takes the US into isolationism because of the domestic humanitarian crisis. The crisis needs to be solved before the US actively participating in international institutions and organizations. However, Trump does not close the possibility of cooperating with other countries with a better terms for the US. Trump conducts his realist action by his attempt to prioritize the US citizens security above anything else. Trump believes that US domestic security is the leading national interest that should be maintained. Moreover, The White House has stated that Trump's effort in combatting the southern border security has delivered result proven by agreements with Mexico, El Salvador, Honduras, and Guatemala regarding the issue. Mexican government is willing to send troops for keeping the border and requires the aliens to wait in Mexico during the cases proceed. While the rest three countries agree to negotiate on asylum.

\section{References}

[1] Dunne, T., \& Schmidt, B. C. (2006). Realism. Dalam J. Baylis, \& S. Smith, (Eds) The Globalization of World Politics: An Introduction to International Relations (3rd ed) (pp. 161-183). Oxford: Oxford University Press.

[2] Gelb, L. H. (1975, November 30). Realism Vs. Idealism in American Foreign Policy. Retrieved from The New York Times: https://www.nytimes.com/1975/11/30/archives/realism-vs-idealism-inamerican-foreign-policy.html

[3] Haass, R. N. (2004). United States after the Cold War. Warsaw: Von Borowiecky.

[4] Krogstad, J. M., \& Passel, J. S. (2014, December 30). Pew Research Center. Retrieved from Fact tank news in number: https://www.pewresearch.org/fact-tank/2014/12/30/u-s-borderapprehensions-of-mexicans-fall-to-historic-lows/ 
[5] Martinez, G. (2019, January 9). Read the Full Transcript of Democrats' Response to President Trump's Oval Office Address. Retrieved from TIME Politic: https://time.com/5497590/nancy-pelosichuck-schumer-trump-transcript/

[6] Martinez, G. (2019, January 9). Read the Full Transcript of President Trump's Oval Office Address on the Border Wall. Retrieved from Time Politic: https://time.com/5497569/donald-trumpoval-office-address-transcript/

[7] Niquette, M. (2019, May 30). Trump Said Mexico Would Pay for the Border Wall. Now What? Retrieved from The Washington Post: https://www.washingtonpost.com/business/trump-said-mexicowould-pay-for-the-border-wall-now-what/2019/05/30/905765a6-828f-11e9-b585-

e36b16a531aa_story.html

[8] Papademetriou, D. G. (2020). A Grand Bargain: Balancing the National Security, Economic, and Immigration Interests of the US and Mexico. Washington DC: Migration Policy Institute.

[9] Rodgers, L., \& Bailey, D. (2019, September 27). Trump wall - all you need to know about US border in seven charts. Retrieved from BBC News: https://www.bbc.com/news/world-us-canada46824649

[10] Sinkkonen, V. (2018). Contextualizing The "Trump Doctrine". Realism, Transactionalism and Civilizational Agenda. Finnish Institute of International Affairs (FIIA) Analysis, 1-25.

[11] The White House Official Website. (2019, September 26). President Donald J. Trump's Humanitarian and Responsible Approach On Refugees Protects the Welfare of American Citizens. Retrieved from The White House: https://www.whitehouse.gov/briefings-statements/president-donaldj-trumps-humanitarian-responsible-approach-refugees-protects-welfare-american-citizens/

[12] The White House Official Website. (2019, October 8). President Donald J. Trump's Efforts to Combat the Crisis at Our Southern Border Are Delivering Results. Retrieved from The White House Immigration Section: https://www.whitehouse.gov/briefings-statements/president-donald-j-trumpsefforts-combat-crisis-southern-border-delivering-results/

[13] Wasko-Owsiejczuk, E. (2018). The Tenets of Trumpism - from Political Realism to Populism. Retrieved from https://www.researchgate.net/publication/328015755_The_Tenets_of_Trumpism__from_Political_Realism_to_Populism

[14] Zajac, E. J. (2006). The concept of US foreign policy after the Cold War, in: US foreign policy. Torun. 